\title{
Dopamine-Sensitive Anticonvulsant Site in the Rat Striatum
}

\author{
Lechoslaw Turski,, ${ }^{1, a}$ Esper A. Cavalheiro, ${ }^{2}$ Zuner A. Bortolotto, ${ }^{2}$ Chrysanthy Ikonomidou-Turski, ${ }^{1}$ Zdzislaw \\ Kleinrok, ${ }^{1}$ and Waldemar A. Turski ${ }^{1}$ \\ 'Department of Pharmacology, Medical School, Jaczewskiego 8, PL-20-090 Lublin, Poland, and 'Department of Neurology \\ and Neurosurgery, Laboratory of Experimental Neurology, Escola Paulista de Medicina, CEP-04023 Sao Paulo, SP, Brazil
}

\begin{abstract}
The basal ganglia are involved in the organization of movement and function in the initiation and expression of generalized and limbic seizures. Dopamine is the principal neurotransmitter of the mesencephalic efferent pathways terminating in the mammalian striatum. No function has been ascribed to mesostriatal dopamine in the control of seizure spread in the brain. This work presents evidence that bilateral application of picomole amounts of apomorphine (a dopamine agonist) into the striatum confers protection against seizures produced by pilocarpine (a cholinergic agonist) in rats. The anticonvulsant effect of apomorphine is topographically confined to the caudate-putamen, nucleus accumbens, and olfactory tubercle. Bilateral application of nanomolar amounts of haloperidol (a dopamine antagonist) into the caudate-putamen or systemic application of haloperidol both lower the threshold for pilocarpine-induced seizures. Local application of an excitatory amino acid $\mathbf{N}$-methyl-Daspartate, into the substantia nigra pars compacta, ventral tegmental area, or retrorubral area, sites of origin of mesostriatal dopaminergic pathways, protects rats against seizures produced by pilocarpine. These results suggest that dopaminergic transmission in the striatum may be operative in complex neuronal networks modulating the seizure threshold.
\end{abstract}

It was in the 1960 s that neurologists began to see a relationship between monoamines and the basic mechanisms of epilepsies (Barsa and Kline, 1955; Hornykiewicz, 1966; Sherwin and van Gelder, 1986). High-dose neuroleptic treatment markedly decreases the threshold for electroshock therapy in nonepileptic patients and dramatically increases the frequency of seizures in patients with previously controlled epilepsy (Barsa and Kline, 1955). One of the clearest bits of experimental evidence of a role for catecholamines in the control of seizure spread has come from the kindling studies in rodents (McNamara et al., 1985). From this work the concept has emerged that brain norepinephrine is engaged in the termination of seizures (McNamara et al., 1985; Burchfiel et al., 1986). The possible role for do-

\footnotetext{
Received Aug. 3, 1987; revised Mar. 28, 1988; accepted Apr. 1, 1988.

This work was supported by project grants from the Polish Academy of Sciences, Conselho Nacional de Pesquisas Cientificas e Tecnologicas, Fundacao de Amparo a Pesquisa do Estado de Sao Paulo and Financiadora de Estudos e Projetos.

Correspondence should be addressed to Dr. L. Turski, Department of Neuropsychopharmacology, Schering AG, P.O. Box 650311 , Sellerstr. 6-8, D-1000 Berlin 65 , F.R.G.

a Present address: Department of Neuropsychopharmaogy, Schering AG, Sellerstr. 6-8, P.O. Box 650311, D-1000 Berlin 65, F.R.G.

Copyright (c) 1988 Society for Neuroscience $0270-6474 / 88 / 114027-11 \$ 02.00 / 0$
}

paminc (DA) in the control of scizurc propagation has been generally neglected (Albala et al., 1986; Lewis et al., 1987).

A breakthrough came from the work of Meldrum and associates, who showed an anticonvulsant action of the DA agonist apomorphine against sound-induced convulsions in genetically seizure-prone DBA/2 mice and against photically induced seizures in baboons (Anlezark and Meldrum, 1975; Meldrum et al., 1975). Apomorphine has also been shown to prevent photically induced myoclonic epilepsy in humans (Quesney et al., 1980). Evidence has been provided on DA depletion and on the decrease of ${ }^{3} \mathrm{H}$-spiroperidol binding in the amygdala of pentylenetetrazol-kindled rats (Gee et al., 1979), as well as on an increase of the DA turnover rate in the forebrain of amygdalakindled rats (Engel and Sharpless, 1977; Wilkison and Halpern, 1979). The concentration of DA is lower in the lumbar cerebrospinal fluid in epileptics (Hiramatsu et al., 1982) and in epileptic foci in human brain (Mori et al., 1987). Conversely, in rodents both DA agonists and antagonists have been found not to be effective against either electroshock- or chemically induced seizures, nor did they affect the development of amygdala kindling (Callaghan and Schwark, 1979; Meldrum et al., 1986).

These findings complicated the understanding of the role DA plays in scizures. The apparent disparity between clinical observations (Barsa and Kline, 1955; Hornykiewicz, 1966) and experimental data (Albala et al., 1986; Corcoran, 1981; McIntyre, 1981) led us to examine the function of mesostriatal DAergic pathways in the buildup of limbic seizures induced in rats by the cholinergic muscarinic agonist pilocarpine. This experimental model of epilepsy offers an attractive feature by allowing intractable seizures and status epilepticus to be induced rapidly after application of the drug and "spontaneous motor seizures" to be observed in the long-term periods after treatment (Turski et al., 1983). The convulsions induced by pilocarpine in rodents have proven to be a reliable variable for investigating the anatomical substrates essential for the generation, spread, and motor expression of seizures (Clifford et al., 1987; Turski et al., 1984, 1987a-c).

The rat striatum is composed of the caudate putamen (CP), nucleus accumbens (ACB), and olfactory tubercle (OTU) (Heimer et al., 1985). The CP receives a dense network of DAcontaining fibers arising from the substantia nigra, pars compacta (SNC) and the retrorubral area (RR) (Björklund and Lindvall, 1984) and projects to the pars reticulata (SNR), entopeduncular nucleus, and globus pallidus/subthalamic nucleus (Iversen, 1977; McGeer et al., 1984; Heimer et al., 1985). The $\mathrm{ACB}$ and OTU receive DA-containing fibers originating in the ventral tegmental area (VTA) and project to the SNR and globus 
Table 1. Stereotaxic coordinates for microinjections according to the atlas of König and Klippel (1963)

\begin{tabular}{|c|c|c|c|c|}
\hline \multirow[b]{2}{*}{ Target site } & & \multicolumn{3}{|c|}{ Stereotaxic coordinates } \\
\hline & & AP & $\mathrm{L}$ & $\mathrm{V}$ \\
\hline \multicolumn{5}{|c|}{ Caudate putamen (CP) } \\
\hline Anterior & A 9410 & 9.41 & $1.0-2.6$ & -0.6 to +2.0 \\
\hline Midanterior & A 8920 & 8.92 & $1.4-2.8$ & -1.4 to +2.0 \\
\hline Midposterior & A 7470 & 7.47 & $1.4-3.6$ & -1.6 to +2.2 \\
\hline Posterior & A 6360 & 6.36 & $2.0-4.5$ & -1.6 to +2.0 \\
\hline \multicolumn{5}{|c|}{ Nucleus accumbens (ACB) } \\
\hline A $9820-$ A 9410 & & $9.41-9.82$ & $0.6-1.6$ & -1.0 to 0.0 \\
\hline \multicolumn{5}{|c|}{ Globus pallidus (GP) } \\
\hline A 6360 & & 6.36 & $2.0-3.0$ & -1.6 to +0.2 \\
\hline \multicolumn{5}{|c|}{ Substantia nigra pars compacta (SNC) } \\
\hline A $1950-$ A 1610 & & $1.61-1.95$ & $1.3-2.0$ & -2.6 to -1.6 \\
\hline \multicolumn{5}{|c|}{ Substantia nigra pars reticulata (SNR) } \\
\hline A $1950-$ A 1610 & & $1.61-1.95$ & $1.0-2.6$ & -3.0 to -1.6 \\
\hline \multicolumn{5}{|c|}{ Ventral tegmental area (VTA) } \\
\hline A 2180 & & 2.18 & $0.4-0.8$ & -2.8 to -2.5 \\
\hline \multicolumn{5}{|c|}{ Retrorubral area (RR) } \\
\hline A 1270 & & 1.27 & $1.8-2.4$ & -2.0 to -1.4 \\
\hline \multicolumn{5}{|c|}{ Olfactory tubercle (OTU) } \\
\hline A $9410-$ A 8920 & & $8.92-9.41$ & $1.0-2.0$ & -2.2 to -2.0 \\
\hline
\end{tabular}

AP, anterior/posterior; L, lateral; V, ventral.

pallidus (Björklund and Lindvall, 1984; McGeer et al., 1984). The substantia nigra has proved essential for the motor expression of seizures in rats, dogs, and monkeys (Hayashi, 1953; Iadarola and Gale, 1982; McNamara et al., 1984). The striatal output pathways terminating in the SNR and entopeduncular nucleus modulate the seizure threshold of the limbic system (Patel et al., 1986; Turski et al., 1986a, 1987b, c). The question arises as to whether DA governs the striatal output pathways that are responsible for these effects.

Some of these data have been communicated to the Meeting of the Society for Neuroscience in Washington D.C. (Cavalheiro and Turski, 1986).

\section{Materials and Methods}

Animals. Male Wistar rats, $230-250 \mathrm{gm}$ in weight, were individually housed under environmentally controlled conditions (6:00 a.m.-6:00 p.m. light/dark cycle; $22-24^{\circ} \mathrm{C}$ ) and permitted free access to food and water. The assignment of rats to experimental groups was performed by means of a randomized method. The behavioral observations and monitoring of the EEG took place between 8:00 a.m. and 6:00 p.m.

Drugs and stereotaxic surgery. The rats were anesthetized with sodium pentobarbital (Nembutal; Ceva, Neuilly-sur-Seine, France), $50 \mathrm{mg} / \mathrm{kg}$ i.p., and implanted with guide cannulae directed towards $\mathrm{CP}, \mathrm{ACB}$, OTU, GP, SNC, VTA, or RR (König and Klippel, 1963). Coordinates for microinjections are shown in Table 1.

The microinjections were performed bilaterally in unanesthetized rats 4-5 d after surgery. The drugs were delivered in a volume of $0.2 \mu \mathrm{l}$ (SNC, VTA, and RR) or $0.5 \mu \mathrm{l}(\mathrm{CP}, \mathrm{ACB}, \mathrm{OTU}$, and GP) at a rate of 0.04 or $0.1 \mu \mathrm{l} / \mathrm{min}$. No rats were used for more than one microinjection.

Pilocarpine hydrochloride (Sigma, St. Louis) was administered i.p. in doses of 200 (nonconvulsant) and $380 \mathrm{mg} / \mathrm{kg}$ (convulsant). Scopolamine methylnitrate (Sigma), $1 \mathrm{mg} / \mathrm{kg}$, was administered s.c. $30 \mathrm{~min}$ prior to the injection of pilocarpine to limit peripheral toxic effects (Turski et al., 1983). Apomorphine hydrochloride (Woelm, Eschwege, FRG) was given into the CP in doses $0.5,1,2$, and 4 pmol $15 \mathrm{~min}$ prior to i.p. injection of pilocarpine, $380 \mathrm{mg} / \mathrm{kg}$. Apomorphine, $2 \mathrm{mg} / \mathrm{kg}$, was also administered s.c. $5 \mathrm{~min}$ prior to pilocarpine, $200 \mathrm{mg} / \mathrm{kg}$. Haloperidol (Janssen, Beerse, Belgium) was administered into the CP in doses of 1 , $2.5,5$, and $10 \mathrm{nmol} 30 \mathrm{~min}$ prior to the injection of pilocarpine, 200 $\mathrm{mg} / \mathrm{kg}$. Haloperidol, $1,2,4$, and $8 \mathrm{mg} / \mathrm{kg}$, was also given i.p. $1 \mathrm{hr}$ prior to the injection of pilocarpine, $200 \mathrm{mg} / \mathrm{kg}$. SKF-38393 [RS-1-phenyl2,3,4,5-tetrahydro-(1H)-3-benzazepine-7,8-diol hydrochloride] (Smith Kline and French Research Laboratories, Philadelphia) and LY-171555 [trans-(-)-4aR-4,4a, 5,6,7,8,8a,9-octahydro-5-propyl-1 ${ }^{-} \mathrm{H}$ (or ${ }^{2} \mathrm{H}$ )-pyrazolo-3,4-g-quinoline monohydrochloride] (quinpyrrole; Lilly Research Laboratories, Indianapolis, IN) were applied into the CP in the dose of $4 \mathrm{pmol} 15 \mathrm{~min}$ prior to the injection of pilocarpine, $380 \mathrm{mg} / \mathrm{kg}$. SCH23390 [(R)-(+)-8-chloro-2,3,4,5-tetrahydro-3-methyl-5-phenyl-1H-3benzazepin-7-ol hemimaleate] (Schering Research Laboratories, Bloomfield, NJ) was given into the $C P$ in the dose of $10 \mathrm{nmol} 30 \mathrm{~min}$ prior to the injection of pilocarpine, $200 \mathrm{mg} / \mathrm{kg}$. SCH-23390, $1 \mathrm{mg} / \mathrm{kg}$, was also given s.c. $1 \mathrm{hr}$ prior to the injection of pilocarpine, $200 \mathrm{mg} /$ kg. Prazosin (Pfizer, Brussels) was injected i.p. in a dose of $10 \mathrm{mg} / \mathrm{kg}$ $30 \mathrm{~min}$ prior to pilocarpine, $200 \mathrm{mg} / \mathrm{kg}$. $N$-Methyl-D-aspartate (NMDA; Tocris, Buckhurst Hill, Essex, U.K.) was administered into the SNC, VTA, or RR in the dose of 200 pmol 15 min prior to the injection of pilocarpine, $380 \mathrm{mg} / \mathrm{kg}$ (Turski et al., 1986a). Figure $1, A$ and $B$ demonstrates the sequence of intracerebral and systemic injections of drugs under study prior to the treatment of rats with pilocarpine, 200 or 380 $\mathrm{mg} / \mathrm{kg}$.

The criteria used to indicate convulsive response to pilocarpine were status epilepticus, defined as continuous motor seizures [stage IV/V according to Racine (1972)] persisting for a period of at least $30 \mathrm{~min}$ before spontaneous termination, and unequivocal tissue pathology. The criterion used to indicate protection from seizures was prevention of limbic seizures and status epilepticus and no sign of tissue pathology (Olney et al., 1983; Turski et al., 1987c).

The dose of apomorphine required to block the seizure response in $50 \%$ of rats ( $\mathrm{ED}_{50}$; effective dose) given $380 \mathrm{mg} / \mathrm{kg}$ of pilocarpine, and the dose of haloperidol required to trigger seizures in $50 \%$ of rats given $200 \mathrm{mg} / \mathrm{kg}$ of pilocarpine was determined by computer analysis of the data obtained from 4 experiments with different dosages. The incidence of seizure response (probit transformed percentages) was plotted versus log dose of the drug administered into the CP. The $\mathrm{ED}_{50}$ and the confidence limits were estimated by fitting the data by linear-regression analysis.

Electroencephalography. For EEG recordings (Beckman model RM polygraph, time constant $0.03 \mathrm{sec}$, high cut-off filter $15 \mathrm{~Hz}$ ), bipolar twisted electrodes (tip diameter, $100 \mu \mathrm{m}$; interelectrode distance, 500 $\mu \mathrm{m})$ were positioned in the dorsal hippocampus. Surface recordings were led from screws positioned bilaterally over the occipital cortex. The correct location of the implanted deep electrodes was histologically controlled in cresyl violet-stained serial sections. 


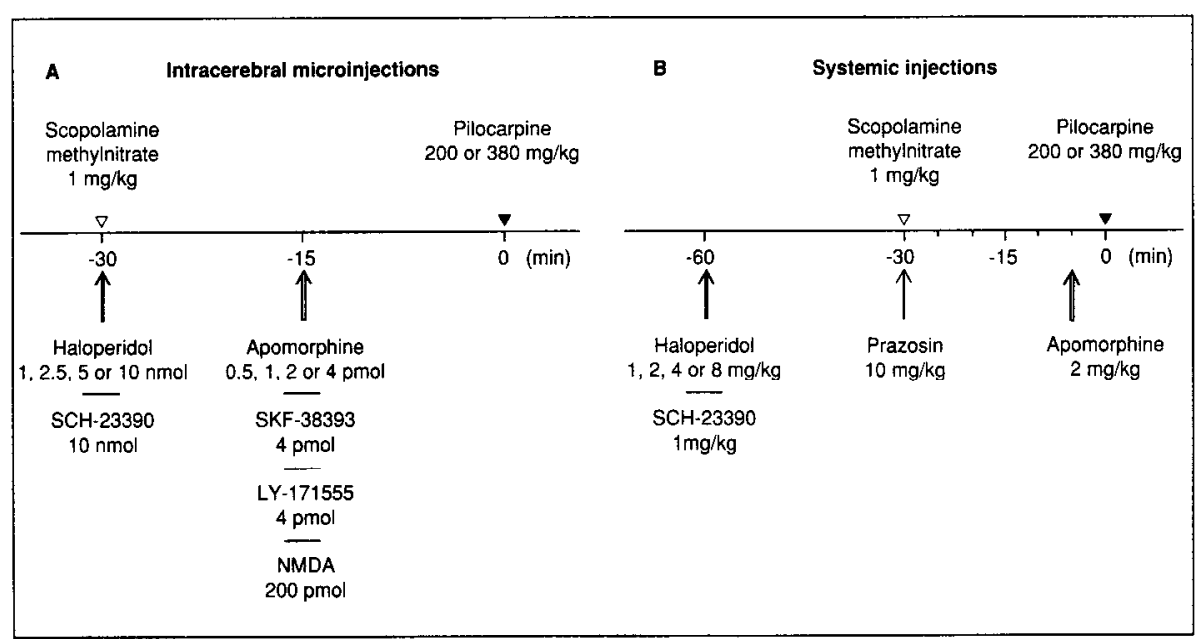

Figure 1. Sequence of intracerebral $(A)$ and systemic $(B)$ injections of drugs used to modulate seizures induced by pilocarpine in rats.
Morphological techniques. The brains were processed for morphological examination by light microscopy 3-15 d after the administration of pilocarpine. The rats were anesthetized with an overdose of sodium pentobarbitone (Ceva) and perfused with fixative containing $10 \%$ acetic acid, $10 \%$ formaldehyde, and $80 \%$ methanol. The brains were fixed in situ at $4^{\circ} \mathrm{C}$ for $24 \mathrm{hr}$, then removed and processed for paraffin embedding. Subsequently, serial sections of the entire brain were cut coronally at $10 \mu \mathrm{m}$, with every 10 th section being mounted on a glass slide and stained with cresyl violet or according to the Fink and Heimer (1967) technique.

\section{Results}

Convulsant action of pilocarpine

A convulsant dose of pilocarpine, $380 \mathrm{mg} / \mathrm{kg}$, produced an array of persistently recurring behavioral alterations in rats. After an initial period of akinesia lasting 3-5 min, ataxic lurching, gustatory automatisms and head tremor dominated animals behavior for 10-15 min. This behavior progressed to limbic seizures (LS) with rearing, forelimb clonus, salivation, masticatory jaw movements, and falling after a delay of 20-30 min. LS recurred every 2-10 min and led to status epilepticus after 40$60 \mathrm{~min}$. Animals that exhibited such seizure activity displayed acute brain damage involving the amygdaloid complex, thalamus, pyriform and entorhinal cortex, hippocampus, septum, neocortex, and substantia nigra. The time course, spectrum, and quality of behavioral alterations, and morphological sequelae of seizures elicited by pilocarpine, $380 \mathrm{mg} / \mathrm{kg}$, in rats receiving bilateral microinjections of solvent into the striatum, substantia nigra, VTA, or RR $(n=25)$ did not differ from those monitored following application of pilocarpine in sham-operated or drugnaive rats.

\section{Apomorphine protects against pilocarpine-induced seizures}

The initial approach was to microinject apomorphine, a mixed $D_{1} / D_{2}$ agonist, into different subregions of the rat striatum prior to systemic administration of a convulsant dose of pilocarpine, $380 \mathrm{mg} / \mathrm{kg}$. Microinjections of apomorphine, $20 \mathrm{pmol}$, into the anterior and midanterior CP (AP 9650-8620) $15 \mathrm{~min}$ prior to pilocarpine, $380 \mathrm{mg} / \mathrm{kg}$, protected rats (4/4) against seizures. No protective effect occurred in the mid- (AP 7890-7020) (0/5) and posterior (AP 6670-5910) (0/4) parts of the CP. The anterior part of the CP was therefore selected for determination of the $\mathrm{ED}_{50}$ of apomorphine. Apomorphine was microinjected into the anterior CP in doses of $0.5(n=4), 1(n=6), 2(n=5)$, and 4 $(n=10)$ pmol. The $\mathrm{ED}_{50}$ of apomorphine for blockade of limbic seizures produced by pilocarpine, $380 \mathrm{mg} / \mathrm{kg}$, is $1.6 \mathrm{pmol}(1.1-$ $2.2 ; n=25$ ). Microinjection of apomorphine, $0.5 \mathrm{pmol}$, into the $\mathrm{CP}$ did not protect against seizures produced by pilocarpine, $380 \mathrm{mg} / \mathrm{kg}$. Apomorphine, $1 \mathrm{pmol}$, microinjected into the CP prevented seizures in 1 out of 6 rats, while 2 pmol prevented evolution of seizures in 2 out of 5 rats. At the dose of 4 pmol, apomorphine protected all 10 rats against the convulsant action of pilocarpine, $380 \mathrm{mg} / \mathrm{kg}$. The dose of $4 \mathrm{pmol}$, which is approximately $\mathrm{ED}_{100}$, was selected for delineation of topography of the anticonvulsant action of apomorphine in the striatum. Apomorphine, 4 pmol, microinjected into the striatum did not result in motor alterations disturbing the rats' normal behavior.

Microinjections of apomorphinc, $4 \mathrm{pmol}$, into most anterior parts of the CP extending from AP 9650 to 8620 conferred protection against pilocarpine-induced seizures (41/41) (Fig. 2). No dorsal-ventral dichotomy in the anticonvulsant action of apomorphine in the anterior CP was found. No clear-cut protective effect of apomorphine, 4 pmol, occurred after microinjections in the mid- (AP 7890-7020; 5/21) and posterior (AP $6670-5910 ; 3 / 15)$ part of the $\mathrm{CP}$. Electrographic monitoring confirmed that microinjections of apomorphine, 4 pmol, into the rostral CP blocked the seizure activity produced by pilocarpine, $380 \mathrm{mg} / \mathrm{kg}$ (Fig. 3). Morphological analysis of the brains from rats treated with apomorphine in the anterior $\mathrm{CP}$ and subjected to the action of pilocarpine, $380 \mathrm{mg} / \mathrm{kg}$, revealed no pathological alterations (Fig. 5). Local application of apomorphine, 4 pmol, into the ACB (11/13) and OTU (5/6) also conferred protection against seizures induced by pilocarpine, 380 $\mathrm{mg} / \mathrm{kg}$ (Fig. 2). Microinjections of apomorphine, $4 \mathrm{pmol}$, into the globus pallidus $(9 / 10)$ and overlying neocortex (4/4) did not result in an anticonvulsant effect (Fig. 2). Apomorphine, 4 pmol, had the most potent anticonvulsant activity in the anterior and midanterior part of the CP (AP 9650-8620), ACB, and OTU (Fig. 2). There was neither seizure response nor brain pathology in 57 out of 60 rats receiving apomorphine in this part of the striatum. The remaining 3 animals ( 2 microinjected into ACB and 1 into OTU) displayed seizures and status epilepticus of markedly delayed onset of approximately $3 \mathrm{hr}$ and had an attenuated pattern of brain damage. The rats receiving microinjections of apomorphine, $4 \mathrm{pmol}$, into the mid- or posterior parts of the CP (AP 7890-7020 and AP 6670-5910) displayed severe status epilepticus with rapid onset of seizures $(24.5 \pm$ $5.3 \mathrm{~min} ; n=28$ ), followed by widespread damage to the forebrain. Eight out of 36 rats treated with apomorphine in the mid- 
and posterior parts of $\mathrm{CP}$ displayed no seizures and showed no tissue pathology in the brain. Pilocarpine, $380 \mathrm{mg} / \mathrm{kg}$, in rats microinjected with apomorphine, 4 pmol, into the GP consistently caused severe seizures of rapid onset $(18.7 \pm 7.3 \mathrm{~min} ; n$ =9) and an extreme pattern of tissue damage. Microinjections of apomorphine into the neocortex $(n=4)$ affected neither the time course nor pathological sequelae of pilocarpine-induced seizures.

To determine the relative role of $D_{1}$ and $D_{2}$ DA receptor stimulation in mediating the anticonvulsant effect of apomorphine in the rat striatum, we have examined the effects of $D_{1}$ agonist SKF-38393 (Setler et al., 1978) and $\mathrm{D}_{2}$ agonist LY171555 (Tsuruta et al., 1981) on seizures induced by pilocarpine. SKF-38393 and LY-171555 were microinjected into the anterior and midanterior $\mathrm{CP}$ in the dose of $4 \mathrm{pmol}$, which is equimolar with maximal anticonvulsant dose of apomorphine in this brain area. The treatment with $D_{2}$ agonist LY-171555 15 min prior to pilocarpine, $380 \mathrm{mg} / \mathrm{kg}$, protected rats $(5 / 5)$ against seizures. By contrast, the $D_{1}$ agonist SKF-38393 had no protective effect against pilocarpine-induced seizures (0/7). Five out of 7 rats receiving SKF-38393 and pilocarpine, $380 \mathrm{mg} / \mathrm{kg}$, died in the course of severe convulsions.

The anticonvulsant action of apomorphine, $4 \mathrm{pmol}$, in the anterior and midanterior CP (AP 9650-8620) was blocked by either coadministration of a preferential $\mathrm{D}_{2} \mathrm{DA}$ antagonist haloperidol, $1 \mathrm{nmol}(5 / 5)$, or systemic injection of haloperidol, 1 $\mathrm{mg} / \mathrm{kg}(4 / 4)$. Haloperidol, $1 \mathrm{mg} / \mathrm{kg}$, was administered i.p. 45 $\min$ prior to focal injection of apomorphine. Haloperidol, 1 $\mathrm{nmol}$, when administered into the anterior $\mathrm{CP}$, or haloperidol, $1 \mathrm{mg} / \mathrm{kg}$, when injected systemically, had no effect on the threshold for seizures elicited by pilocarpine.

\section{Haloperidol}

Microinjections of haloperidol into the anterior and midanterior CP (AP 9650-8620), $30 \mathrm{~min}$ prior to the subconvulsant dose of pilocarpine, $200 \mathrm{mg} / \mathrm{kg}$, led to limbic seizures and status epilepticus with an $\mathrm{ED}_{50}$ of $8.1 \mathrm{nmol}(4.6-14.3 ; n=24)$. None of 6 rats receiving haloperidol, $1 \mathrm{nmol}$, displayed seizures following injection of pilocarpine, $200 \mathrm{mg} / \mathrm{kg}$. Microinjection of haloperidol, $2.5 \mathrm{nmol}$, into the $\mathrm{CP}$, prior to pilocarpine, 200 $\mathrm{mg} / \mathrm{kg}$, led to limbic seizures in 1 out of 6 rats. Two out of 7 rats treated with haloperidol, $5 \mathrm{nmol}$, had seizures following subsequent injection of pilocarpine, $200 \mathrm{mg} / \mathrm{kg}$. Three out of 5 rats subjected to microinjection of haloperidol, $10 \mathrm{nmol}$, into the $\mathrm{CP}$ and pilocarpine, $200 \mathrm{mg} / \mathrm{kg}$, displayed the full pattern of convulsive activity. Electrographic sequelae of pilocarpine, $200 \mathrm{mg} / \mathrm{kg}$, in rats pretreated with haloperidol in the anterior and midanterior $\mathrm{CP}$, were similar to that induced by the drug in doses exceeding $350 \mathrm{mg} / \mathrm{kg}$ (Fig. 4). Widespread damage of the forebrain was detected in rats pretreated with haloperidol in the $\mathrm{CP}$, which developed seizures and status epilepticus in response to subconvulsant dose of pilocarpine, $200 \mathrm{mg} / \mathrm{kg}$ (Fig. 5). Microinjections of haloperidol, 5 and $10 \mathrm{nmol}$, into the anterior and midanterior CP (AP 9650-8620) resulted in akinesia and catalepsy, giving positive scores in the bar test during the following 30-60 min.

Systemic injections of haloperidol increased the range and severity of convulsive activity of pilocarpine, $200 \mathrm{mg} / \mathrm{kg}$, in a dose-dependent manner. None of 4 rats subjected to haloperidol, $1 \mathrm{mg} / \mathrm{kg}, 1 \mathrm{hr}$ prior to pilocarpine, $200 \mathrm{mg} / \mathrm{kg}$, developed seizures or status epilepticus. One out of 4 rats receiving haloperidol, $2 \mathrm{mg} / \mathrm{kg}$, had seizures in response to pilocarpine, 200

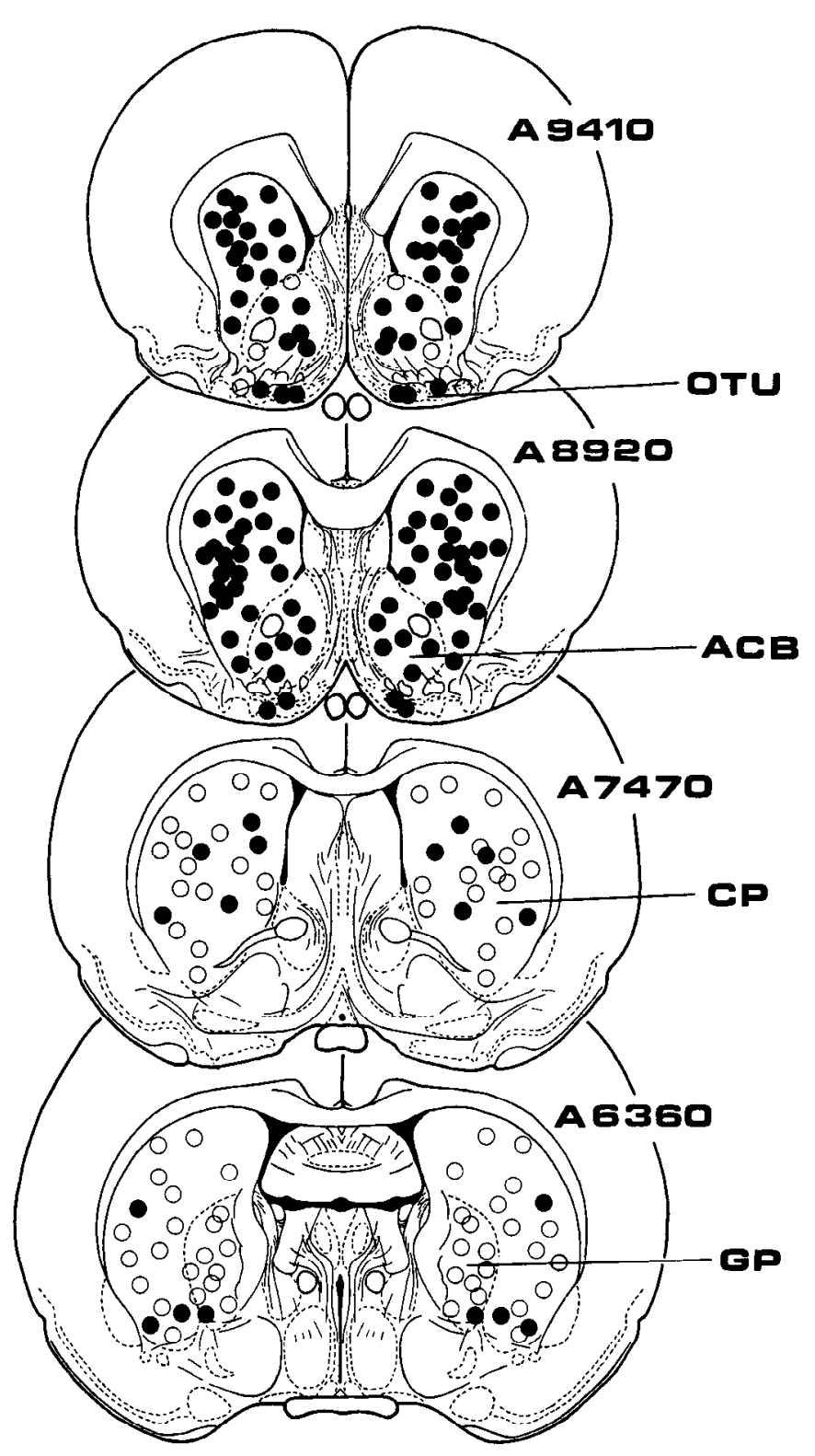

Figure 2. Schematic reconstruction of locations of the tips of the injection cannula tracts in the caudate putamen $(C P)$, nucleus accumbens $(A C B)$, olfactory tubercle (OTU), and globus pallidus (GP) determined histologically in serial coronal sections of perfused rat brain. The diagram of coronal sections of rat brain is based on the atlas of König and Klippel (1963). Apomorphine, 4 pmol, was microinjected bilaterally into CP, ACB, OTU, or GP 15 min prior to i.p. administration of pilocarpine, $380 \mathrm{mg} / \mathrm{kg}$. Dark circles represent sites from which apomorphine protects rats from seizures produced by pilocarpine, $380 \mathrm{mg}$ ' $\mathrm{kg}$; open circles represent sites from which apomorphine does not alter the convulsant action of pilocarpine, $380 \mathrm{mg} / \mathrm{kg}$.

$\mathrm{mg} / \mathrm{kg}$. In 3 out of 6 animals pretreated with haloperidol, $4 \mathrm{mg} /$ $\mathrm{kg}$, pilocarpine, $200 \mathrm{mg} / \mathrm{kg}$, triggered seizures, while all 4 animals treated with haloperidol, $8 \mathrm{mg} / \mathrm{kg}$, displayed convulsions following pilocarpine, $200 \mathrm{mg} / \mathrm{kg}$. The $\mathrm{ED}_{50}$ for haloperidol as a factor triggering seizures in rats treated with pilocarpine, 200 $\mathrm{mg} / \mathrm{kg}$, was $3.0 \mathrm{mg} / \mathrm{kg}(2.0-4.3 ; n=18)$. Haloperidol, $1-8 \mathrm{mg} /$ $\mathrm{kg}$, produced immobility and catalepsy in all tested rats. The proconvulsant effect of haloperidol, $8 \mathrm{mg} / \mathrm{kg}$, was abolished by apomorphine, $2 \mathrm{mg} / \mathrm{kg}$, s.c., administered $55 \mathrm{~min}$ after the neuroleptic and $5 \mathrm{~min}$ prior to pilocarpine, $200 \mathrm{mg} / \mathrm{kg}$ (4/4). Apo- 

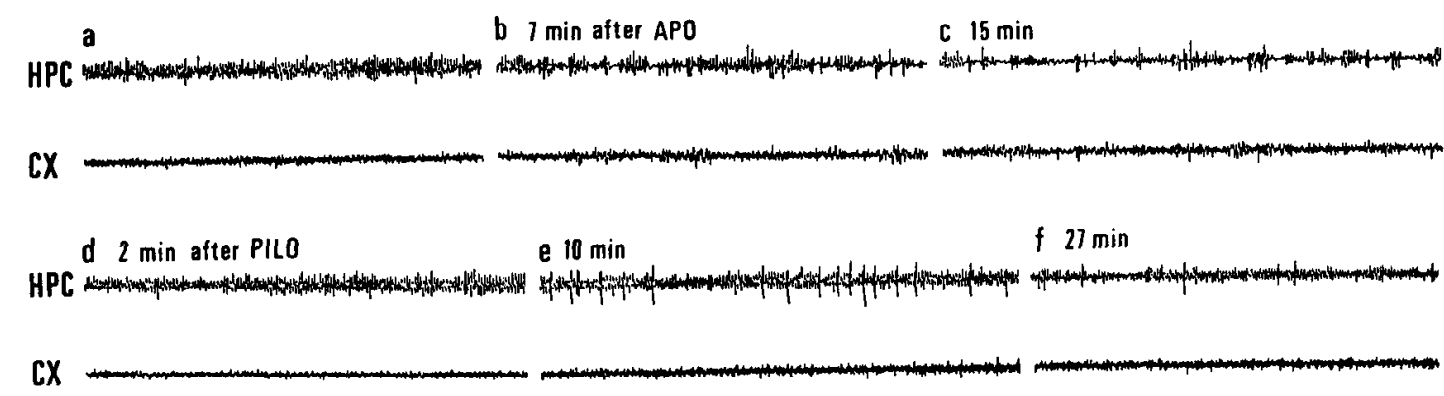
g th
h $2 h$
i $4 \mathrm{~h}$

HPC

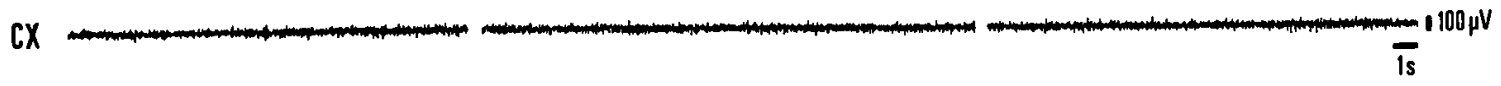

Figure 3. Microinjection of apomorphine hydrochloride ( $A P O), 4$ pmol, into the rostral part of the caudate putamen (CP; AP 9410$)$ blocks the convulsant action of pilocarpine (PILO), $380 \mathrm{mg} / \mathrm{kg}$, given i.p. $15 \min$ later. $a$, Predrug control recordings. $b$ and $c$, Records to demonstrate electrographic events 7 and $15 \mathrm{~min}$ after microinjection of APO into the CP. $d$, Theta rhythm and low-voltage fast activity prevail in hippocampal recordings $2 \mathrm{~min}$ after PILO. $e$, High-voltage fast activity and spikes in the hippocampus 10 min after administration of PILO. $f$ and $g$, Isolated spikes registered exclusively in the hippocampal record and low-voltage fast activity in the cortex 20-60 min after PILO. $h$, Two hours after injection of PILO the EEG progressively normalizes in both hippocampal and cortical recordings. $i$, Four to $6 \mathrm{hr}$ after injection of PILO the EEG returns to the predrug patterns. $C X$, cortex; $H P C$, hippocampus.

morphine, $2 \mathrm{mg} / \mathrm{kg}$, when administered $5 \mathrm{~min}$ prior to pilocarpine, $380 \mathrm{mg} / \mathrm{kg}(n=4)$, did not modify convulsant activity of the drug.

To determine the relative selectivity of $\mathrm{DA} \mathrm{D}_{2}$ receptor blockade in the $\mathrm{CP}$ in mediating the proconvulsant effect of haloperidol, we tested the effect of preferential $\mathrm{D}_{1}$ antagonist $\mathrm{SCH}$ 23390 (Iorio et al., 1983) on susceptibility of rats to seizures induced by pilocarpine. SCH-23390 was microinjected into the anterior and midanterior $\mathrm{CP}$ in the dose of $10 \mathrm{nmol}$, which is equimolar with maximal proconvulsant dose of haloperidol in this brain region. This treatment did not lower the threshold for seizures induced by pilocarpine, $200 \mathrm{mg} / \mathrm{kg}$, in 5 rats $(0 / 5)$. Systemic administration of SCH-23390 in the dose of $1 \mathrm{mg} / \mathrm{kg}$ also failed to increase the susceptibility of rats to pilocarpine, $200 \mathrm{mg} / \mathrm{kg}(0 / 4)$.

Since haloperidol may depress noradrenergic neurotransmission acting via $\alpha_{1}$-receptor (Seeman and Grigoriadis, 1987), a selective $\alpha_{1}$-adrenergic antagonist, prazosin, was injected $30 \mathrm{~min}$ prior to systemic administration of subconvulsant dose of pilocarpine, $200 \mathrm{mg} / \mathrm{kg}$. Such injections of prazosin, $10 \mathrm{mg} / \mathrm{kg}(n=$ 5 ), did not trigger seizures in rats subjected to pilocarpine, 200 $\mathrm{mg} / \mathrm{kg}$.

\section{Mesostriatal dopamine- and pilocarpine-induced seizures}

The second objective of the present study was to characterize the function of the mesostriatal pathways in the control of seizure spread. We approached this problem by microinjecting an excitatory amino acid, NMDA, into the SNC, VTA, or RR. The convulsant action of pilocarpine, $380 \mathrm{mg} / \mathrm{kg}$, was blocked by bilateral microinjections of NMDA, 200 pmol, into the SNC $(7 / 7)$, VTA (4/6), or RR (3/4) as judged by behavioral and electrographic monitoring (Fig. 5) and morphological analysis (Fig. 6). NMDA was administered into the SNC, VTA, or RR 15 min prior to pilocarpine. The anticonvulsant effect of NMDA in the SNC, VTA, and RR is anatomically specific since microinjections of NMDA, $200 \mathrm{pmol}$, into the SNR (0/6) do not modify the convulsions induced by pilocarpine. Focal microinjection studies showed that high-dose treatment with NMDA
(2 and $5 \mathrm{nmol}$ ) in the SNR and not in the SNC lowered the threshold for seizures induced by pilocarpine (Turski et al., 1986a). The anticonvulsant effect of NMDA, $200 \mathrm{pmol}$, in the SNC was abolished by bilateral microinjection of haloperidol, $1 \mathrm{nmol}$, in the anterior and midanterior CP (AP 9650-8620; 6/ 7). Haloperidol was administered into the $\mathrm{CP} 30 \mathrm{~min}$ prior to microinjection of NMDA in the SNC. Microinjections of NMDA, 200 pmol, into the SNC, SNR, VTA, and RR $(n=10)$ did not elicit motor alterations disturbing a normal behavior of rats.

\section{Discussion}

\section{Mesostriatal dopamine and seizures}

These data demonstrate the anticonvulsant potential of the DA agonist apomorphine in the rat striatum in the pilocarpine model of limbic seizures. This effect is topographically confined to the most anterior part of the striatum and can be easily blocked with the DA antagonist haloperidol. The potential significance of these findings is established by the anticonvulsant action of an excitatory amino acid NMDA in the SNC, VTA, and RR, all sites of origin of the DAergic projection to the striatum (Björklund and Lindvall, 1984; Oades and Halliday, 1987). Both systemic or focal microinjections of haloperidol into the anterior CP lower the threshold for pilocarpine-induced seizures. These findings indicate a role for DAergic transmission in the striatum for the propagation and termination of seizures in the limbic neuronal circuits. This may aid the understanding of how the basal ganglia governs the motor expression of seizures and gates the evolution of seizure activity in the forebrain. The clear-cut topographic limitation of the anticonvulsant action of apomorphine to anterior $\mathrm{CP}, \mathrm{ACB}$, and OTU probably explains why several attempts to delineate the function of striatal DA in epileptogenesis have so far failed.

The present results highlight the role of $D_{2}$ DA receptors in the rat striatum in modulating seizures produced by pilocarpine. The most suggestive evidence for the involvement of $D_{2} D A$ receptor-linked mechanisms is provided by the anticonvulsant action of the selective $D_{2}$ receptor agonist $L Y-171555$ in the CP. The selective $D_{1}$ receptor agonist SKF-38393 does not sup- 


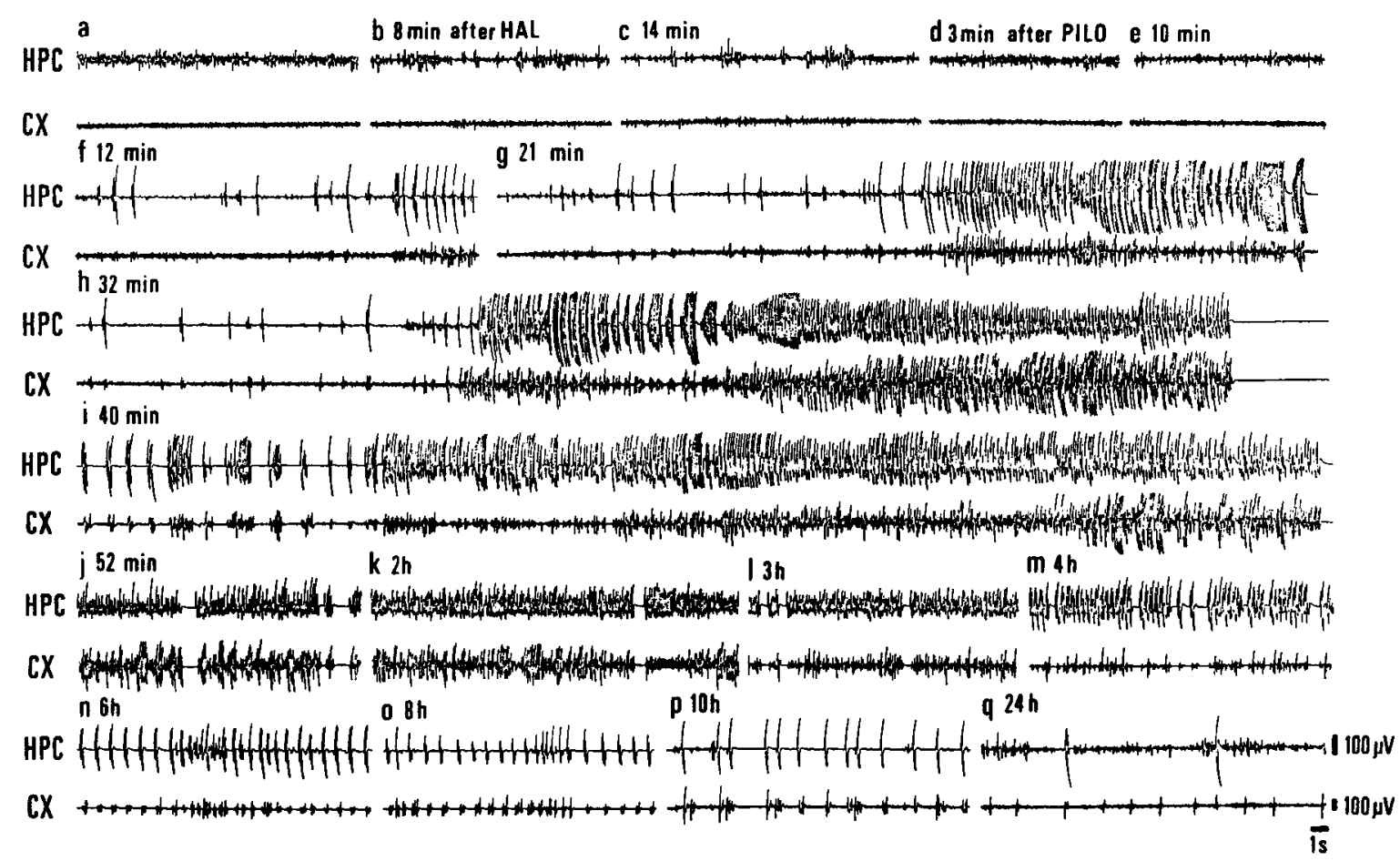

Figure 4. Haloperidol $(H A L)$ decreases the threshold for limbic seizures in rats after microinjection into the rostral part of the caudate putamen (CP; AP 9410). HAL, $5 \mathrm{nmol}$, was microinjected into the CP, bilaterally, $30 \mathrm{~min}$ prior to the injection of pilocarpine $(P I L O), 200 \mathrm{mg} / \mathrm{kg}$, i.p. $a$, Predrug control recordings. $b$ and $c$, Records to demonstrate electrographic events 8 and 14 min after microinjection of HAL into the CP. $d$, Theta rhythm in the hippocampus and fast activity in the cortex registered $3 \mathrm{~min}$ after injection of PILO, $200 \mathrm{mg} / \mathrm{kg}$. $e$ and $f$. High-voltage fast activity superimposes over hippocampal theta rhythm and progresses into the high-voltage spiking registered initially in hippocampal recordings. $g$, Highvoltage spiking in the hippocampus precedes the first electrographic seizure registered 21 min after injection of PILO. $h$ and $i$, Electrographic seizures registered 32 and $40 \mathrm{~min}$ after injection of PILO. Ictal periods recur every 3-5 min and result in a status epilepticus within 40-60 min after PILO. $j, k$, and $l$, Electrographic activity during the status epilepticus $1-3 \mathrm{hr}$ after PILO. $m, n$, and $o$, Progressive normalization of the electrographic activity observed with $4-8 \mathrm{hr}$ postinjection. $p$ and $q$, EEG activity returns to the predrug pattern within $24-48 \mathrm{hr}$, although isolated spikes are registered in both recordings up to $3-5 \mathrm{~d}$ after the injection of PILO. $C X$, cortex; $H P C$, hippocampus.

press pilocarpine-induced seizures following microinjection into the $\mathrm{CP}$. Furthermore, the preferential $\mathrm{D}_{1}$ receptor antagonist SCH-23390 does not enhance the susceptibility of rats to pilocarpine-induced seizures when applied systemically or focally into the CP. Both these pieces of evidence indicate that $D_{1}$ receptors were not involved and are consistent with the hypothesis that the DA receptors mediating modulatory effects of apomorphine and haloperidol on the susceptibility of rats to seizures elicited by pilocarpine are of the $D_{2}$ subtype.

Experimental work with selective $D_{1}$ and $D_{2}$ DA agonists has suggested distinct anticonvulsant activity for preferential $\mathrm{D}_{2}$ agonists in several animal models of convulsions (Löscher and Czuczwar, 1986). The preferential $\mathrm{D}_{2}$ agonists lisuride and (+)4-propyl-9-hydroxynaphthoxazine were found to be effective against air blast-induced seizures in gerbils, amygdala-kindled seizures in rats, and electroconvulsions in mice (Löscher and Czuczwar, 1986). By contrast, the selective $D_{1}$ agonist SKF38393 exerted no anticonvulsant activity in such seizure models (Löscher and Czuczwar, 1986).

These results raise an issue with respect to the mechanisms underlying the anticonvulsant action of DAergic drugs in animal models of seizures. Whereas processes mediated by $D_{2}$ receptors appear to be involved in the suppression of seizures, processes mediated by $D_{1}$ receptors do not exert overt anticonvulsant effect (Löscher and Czuczwar, 1986).

In terms of anticonvulsant efficacy of $D_{2}$ agonists, our observations with pilocarpine-induced seizures provide a parallel to those of Löscher and Czuczwar (1986) but extend them by the demonstration of a proconvulsant action due to $D_{2}$ receptor blockade. Our observations identify the striatum as an important site where $D_{2}$-sensitive mechanisms may exert modulatory action upon seizures.

\section{Dopaminergic modulation of seizures in the basal ganglia: possible mechanisms}

Dopamine exerts a dual effect on neuronal activity of the rat CP (Akaike et al., 1987; Akaoka et al., 1987). Studies using intracellular recording techniques showed that perfusion of the $\mathrm{CP}$ slices with low concentrations of DA produced a depolarization of resting membrane potential and increased the frequency of spontaneous firing (Akaike et al., 1987). High concentrations of DA had no effect on resting membrane potential but inhibited spontaneous firing of CP neurons (Akaike et al., 1987). The excitatory effect of DA in the CP in vitro is reproduced by the specific $\mathrm{D}_{2}$ DA agonists LY-171555 and bromocriptinc following iontophoretic application onto feline caudate neurons (Ohno et al., 1985). Stimulation of the SNC induces EPSPs and spike generation in caudate neurons, which are potentiated by LY-171555 and blocked by the preferential $D_{2}$ antagonists domperidone and haloperidol (Ohno et al., 1986). Studies using extracellular recording techniques in halothaneanesthetized rats showed that iontophoretic application of DA produced inhibition of spontaneously active and glutamate-activated neurons in the CP (Akaoka et al., 1987). Stimulation of 

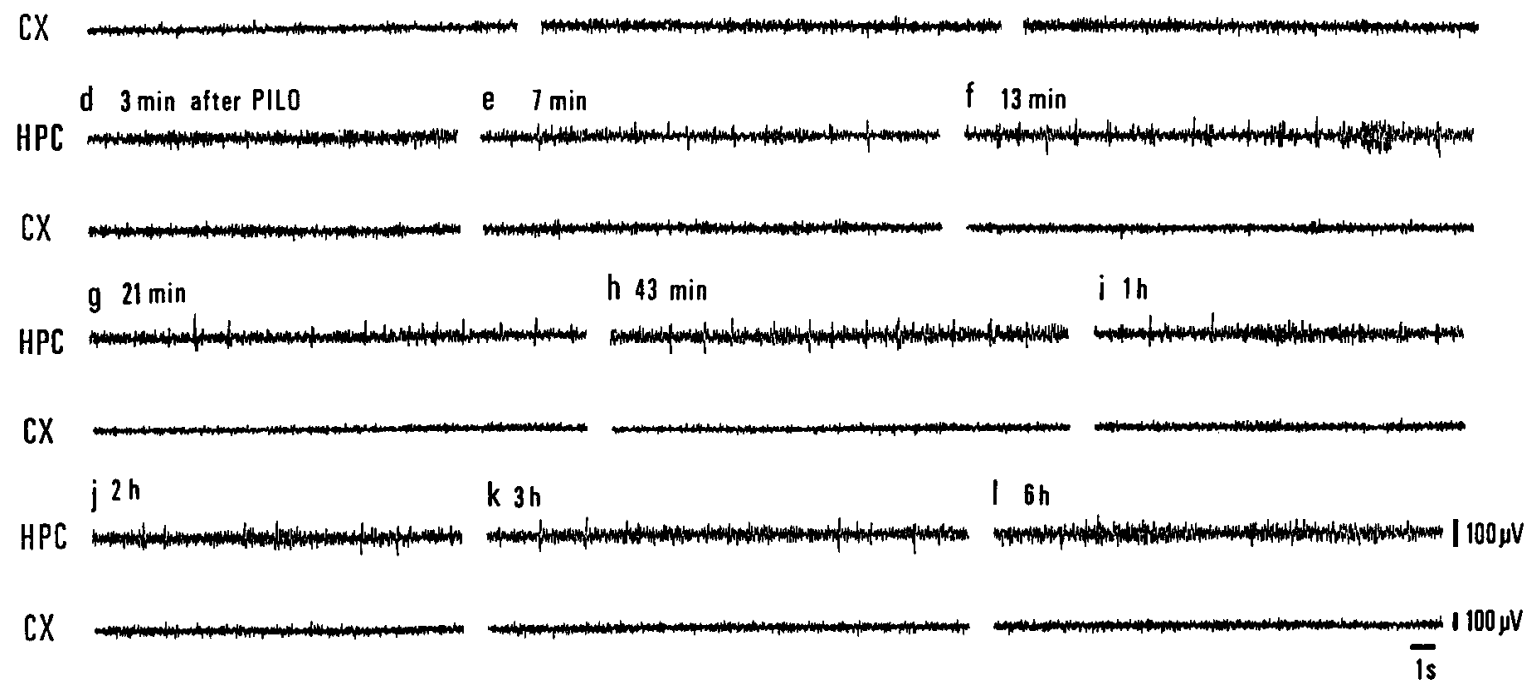

Figure 5. Electrographic recordings from the hippocampus and cortex demonstrating the effect of microinjection of NMDA, 200 pmol, bilaterally, into the substantia nigra, pars compacta on the convulsant action of pilocarpine $(P I L O), 380 \mathrm{mg} / \mathrm{kg}$, i.p., 15 min later. $a$, Predrug control recordings. $b$ and $c$, Unchanged records 8 and 14 min after microinjection of NMDA into the substantia nigra, pars compacta. $d$, Theta rhythm and lowvoltage fast activity dominate EEG $3 \mathrm{~min}$ after the injection of PILO. $e$. Isolated spikes supersede the background activity in the hippocampus $7-$ $10 \mathrm{~min}$ after PILO. $f . g$, and $h$. High-voltage spiking progressively builds up in the hippocampus, while cortical recordings remain unchanged. $i-$ $k$, One to $3 \mathrm{hr}$ after injection of PILO, the EEG progressively normalizes in hippocampal recordings. $l$, Four to $6 \mathrm{hr}$ after injection of PILO, the EEG returns to predrug patterns $(a)$. $C X$, cortex; $H P C$, hippocampus.

median forebrain bundle in such preparations had a mainly inhibitory cffect on CP neurons, although it was sometimes associated with short-latency excitatory responses (Akaoka et al., 1987). Although these findings show that DA exerts a complex profile of actions on the caudate neurons, these data add to understanding of how apomorphine, LY-171555 and chemical stimulation of the SNC with NMDA may exert anticonvulsant effect in the CP in the pilocarpine model of seizures. The finding that haloperidol antagonizes the anticonvulsant effect of chemical stimulation of the SNC conforms with electrophysiological observations on the action of DA and selective DA agonists in the CP (Akaike et al., 1987; Akaoka et al., 1987).

Interactions between dopamine, acetylcholine, and GABA in the basal ganglia and seizure control

The principal DAergic innervation of the rat striatum is derived from nerve terminals of neurons whose perikarya are located in the SNC, VTA, and RR (Björklund and Lindvall, 1984; Oades and Halliday, 1987). The striatum integrates and transforms information coming from the SNC/VTA/RR before it passes to the SNR and globus pallidus/entopeduncular nucleus (Graybiel et al., 1986). Although we are at present unable to explain how the striatum processes incoming information from SNC/VTA $\mathrm{RR}$, largely due to a lack of knowledge about the functional organization of neuronal networks and interplays among transmitter systems within the striatum (Fig. 7), there are several findings that may guide the understanding of striatal function in seizure control.

Acetylcholine (ACh) and GABA are key neurotransmitters in the striatum (Graybiel and Ragsdale, 1983). As judged by microiontophoresis, DA blocks the function of $\mathrm{ACh}$ and GABA in the striatum (Herrling and Hull, 1980; Brown and Arbuthnott, 1983; Mercuri et al., 1985). Conversely, lesioning the ni- grostriatal pathway with 6-hydroxydopamine elevates activity of striatal choline acetyltransferase (an ACh-synthesizing enzyme) and glutamate decarboxylase (a GABA-synthesizing enzyme) (Nagy et al., 1978; Gale and Casu, 1981; Bennett, 1986). $\mathrm{ACh}$ is thought to facilitate GABAergic activity in the striatum (Besson et al., 1982). Given the position striatal DA occupies in modulating the threshold for pilocarpine-induced seizures, one would predict that striatal ACh and GABA determine its capacity in regulating basal ganglia output (Fig. 7). Experimental support for this would be a demonstration of an anticonvulsant effect of cholinergic and GABA antagonists in the striatum. In fact, minute amounts of scopolamine (a cholinergic muscarinic antagonist) and bicuculline methiodide or picrotoxin (GABA antagonists) confer protection against seizures induced by pilocarpine (Turski et al., 1986b, 1987a). Bicuculline methiodide also prevents amygdala-kindled seizures in rats when focally microinjected into the CP (Cavalheiro et al., 1987). Other investigators have found an increase of the binding of GABA to rat striatal membranes following amygdala kindling (Löscher and Schwark, 1987). These data infer that ACh and GABA in the striatum contributes to the regulation of neuronal networks which modulate the seizure threshold of the limbic forebrain.

\section{Topography of the anticonvulsant action of apomorphine in the striatum: morphology and function}

The modern understanding of neuronal architecture of the mammalian striatum is based on compartmentalization of striatal tissue into matrix and striosomes (Gerfen, 1984; Gerfen et al., 1987a, b). The DAergic and cholinergic activity in the striatum is highly concentrated in extrastriosomal matrix (Graybiel et al., 1986; Gerfen et al., 1987b; Loopuijt et al., 1987). The striatal matrix receives cortical afferents and projects to the SNR and globus pallidus/entopeduncular nucleus (Graybiel et al., 

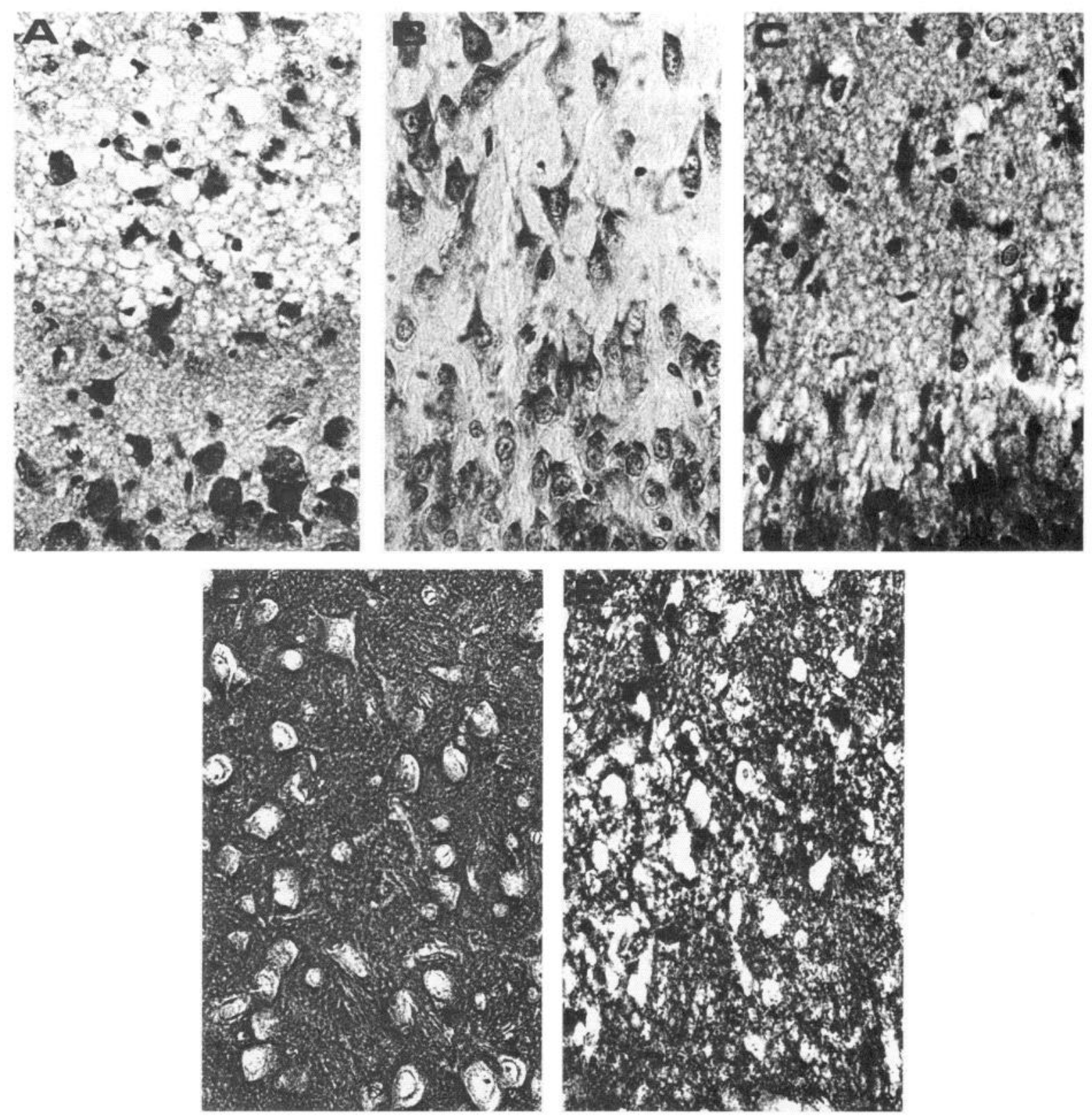

Figure 6. Protection from neuropathological sequelae of seizures induced in rats by pilocarpine after application of apomorphine into the caudate putamen $(C P)$ or NMDA into the substantia nigra pars compacta $(S N C)$. $A$, The pyriform cortex with massive edematous changes and extensive disintegration of the neuropil after seizures induced by pilocarpine, $380 \mathrm{mg} / \mathrm{kg}$, in a rat subjected to microinjection of saline into the CP. Morphological changes were also seen in the thalamus, amygdala, entorhinal cortex, hippocampus, substantia nigra, and temporal cortex. $B$, Normal cytoarchitecture of the pyriform cortex in a rat treated with microinjection of apomorphine, $4 \mathrm{pmol}$, into the $\mathrm{CP}$, and pilocarpine, $380 \mathrm{mg} / \mathrm{kg}$, i.p., $15 \mathrm{~min}$ later. No morphological changes were discernible anywhere in the brain. $C$, Advanced breakdown of morphological structure of the pyriform cortex with edema and extensive disintegration of the neuropil after seizures induced by pilocarpine, $200 \mathrm{mg} / \mathrm{kg}$, in a rat pretreated with haloperidol, $8 \mathrm{mg} /$ $\mathrm{kg}$, i.p. $D$, Unchanged morphology of the lateral thalamic nucleus in a rat subjected to microinjection of NMDA, 200 pmol, into the SNC and pilocarpine, $380 \mathrm{mg} / \mathrm{kg}$, i.p., $15 \mathrm{~min}$ later. $E$, Severe destruction of the lateral thalamic nucleus after seizures induced by pilocarpine, $380 \mathrm{mg} / \mathrm{kg}$, in a rat subjected to microinjection of saline into the SNC. Survival time, 3-15 d. Cresyl violet $(A-C)$ or Fink-Heimer stain $(D$ and $E)$. $\times 196$.

1986; Gerfen et al., 1987b). The DA receptors in the striatal matrix are mainly of the $\mathrm{D}_{2}$ type (Trugman et al., 1986; Loopuijt et al., 1987). The analysis of DA receptor distribution in the rat striatum shows a decreasing gradient along the rostrocaudal axis for both receptor subtypes (Richfield et al., 1987). No gradients in the distribution of muscarinic and GABA receptors have been demonstrated in the rat striatum (Wamsley et al., 1984; Bowery et al., 1987).
The topography of anticonvulsant action of apomorphine in the rat striatum shows a clear-cut decreasing gradient from rostral to caudal and no dorsal to ventral gradients. Other work has shown that striatum is a homogenous entity with respect to anticonvulsant action of scopolamine (Turski et al., 1987a) and bicuculline (Turski et al., 1986b) in rats subjected to seizures induced by pilocarpine. The topographic profile of the anticonvulsant action of apomorphine, scopolamine, and bicuculline 


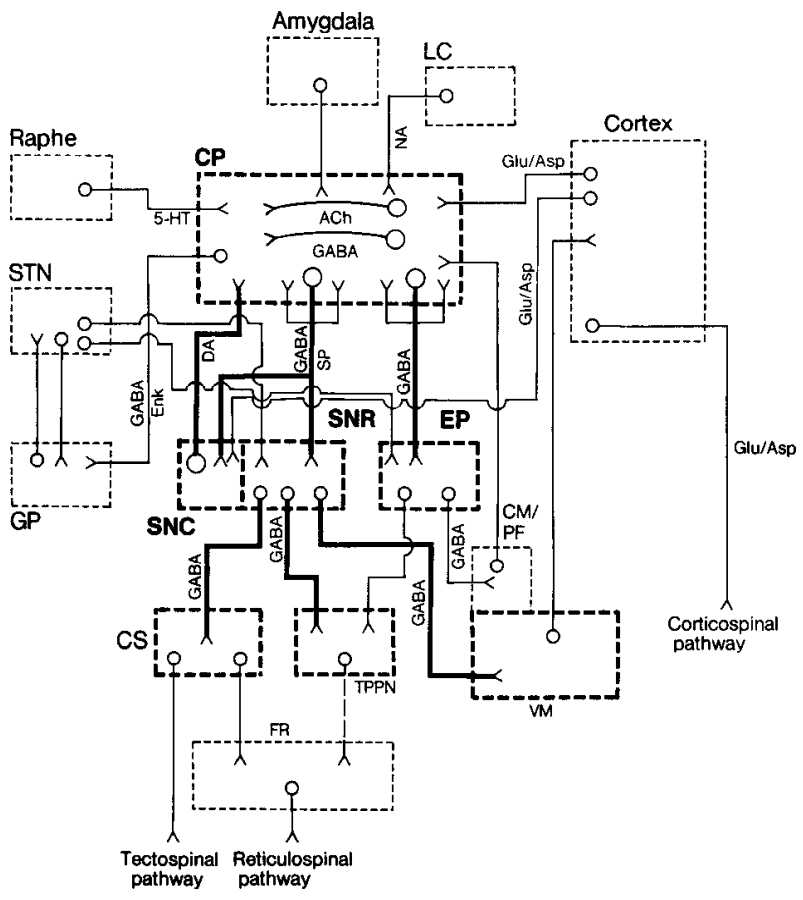

Figure 7. Schematic diagram of efferent and afferent pathways in the rat basal ganglia. $A C h$, acetylcholine; $A s p$, L-aspartate; $C M / P F$, centromedian and parafascicular nucleus thalami; $C P$, caudate putamen; $C S$, colliculus superior; $D A$, dopamine; $E n k$, enkephalin; $E P$, entopeduncular nucleus; $F R$, reticular formation; $G l u$, L-glutamate; $G P$, globus pallidus; $I C$, locus coenuleus; $S T N$, subthalamic nucleus; $N A$, noradrenaline; $S N C$, substantia nigra, pars compacta; $S N R$, substantia nigra, pars reticulata; $S P$, substance $P ; T P P N$, tegmental pedunculopontine nucleus; $V M$, ventromedial thalamic nucleus.

in the striatum matches the functional compartmentalization and morphological organization of this region.

\section{Basal ganglia and epilepsy: a speculative synthesis}

The lesion experiments in rodents showed that basal ganglia may govern the seizure spread in the brain. We have previously reported that bilateral chemical lesions of the $\mathrm{CP}$ with ibotenic acid decreases the threshold for seizures produced by pilocarpine (Turski et al., 1987b). Similarly, bilateral electrolytic destruction of the $\mathrm{CP}$ accelerates the development of pentylenetetrazol kindling and increases severity of audiogenic seizures in rats (Kesner, 1966; Kryzhanovskii et al., 1985). The possible involvement of the basal ganglia in control of the seizure spread in rodents is further indicated by retardation of amygdala kindling in rats following electrical stimulation of the striatum (Amato et al., 1982). Stimulation of the caudate nucleus likewise inhibits the expression of seizures in feline models of convulsions (Mutani, 1969; Wagner et al., 1975; Kusske, 1979; Psatta, 1983). In macaque rhesus monkeys, high-frequency electrical stimulation of the caudate nucleus also decreases the frequency of seizures elicited by cortical placement of alumina gel (Oakley and Ojemann, 1982). In humans, low-frequency electrical stimulation of the caudate nucleus may be beneficial in the control of partial seizures (Chkhenkeli, 1978; Sramka et al., 1980).

It is currently proposed that substantia nigra and entopeduncular nucleus transmit and transform motor information necessary for generalized seizures to occur (Iadarola and Gale, 1982; McNamara et al., 1984; Patel et al., 1986). The striatum possesses only a limited number of efferent pathways, which may be involved in modulating the threshold for seizures in the limbic forebrain (McGeer et al., 1984). The anticonvulsant effect of NMDA (Turski et al., 1987b), scopolamine (Turski et al., 1987a), and bicuculline methiodide (Turski et al., 1986b) in the CP of rats subjected to seizures induced by pilocarpine is reversed by blocking GABA-mediated inhibition in the substantia nigra or entopeduncular nucleus with focal microinjections of bicuculline. This suggests the possible involvement of striatonigral and striatoentopeduncular pathways in the control of propagation of motor seizures to the executive targets. Further proof for the involvement of the basal ganglia in the epileptogenesis is provided by the observation that an increase occurs in the excitability of hippocampal dentate granule cells to perforant pathway stimulation following the focal application of NMDA into, or electrical stimulation of, the substantia nigra (Shin and McNamara, 1986). An anticonvulsant effect of NMDA in the rat SNC in the pilocarpine-induced seizures is similar to that reported in feline SNC following electrical stimulation in penicillin-induced generalized epilepsy (Sabatino et al., 1987). Reversal of anticonvulsant effects of NMDA in the SNC with microinjections of haloperidol into the $\mathrm{CP}$ tends to indicate that mesostriatal pathways are involved in the seizure gating mechanisms. Since the SNC/VTA/RR extensively projects to the prefrontal cortex, entorhinal cortex, septum, and striatum (Björklund and Lindvall, 1984; Oades and Halliday, 1987), these massive DAergic projections can serve a gating function for the propagation of seizure activity. In regard to the last of these, destruction of the CP, septum, entorhinal cortex, and prefrontal cortex differentially modulates seizure spread (Kesner, 1966; Wada and Wake, 1977; Sabatino et al., 1986; Ono et al., 1987; Turski et al., 1987b; White and Gall, 1987).

\section{Conclusion}

The striatum comprises a network of neurochemically and morphologically distinct but functionally interactive compartments (Gerfen, 1984; Graybiel et al., 1986; Gerfen et al., 1987b). Striatal input and output projections are topographically ordered and process the flow of sensory and motor information required for setting of the gains and biases in the executive motor centers in accordance with the pattern of motor output selected (DeLong et al., 1984). The basal ganglia are widely concerned in movement disorders such as parkinsonism and Huntington's disease (Marsden, 1984). Our observations provide evidence that certain aspects of epileptogenesis may also be subject to control by the basal ganglia.

\section{References}

Akaike, A., Y. Ohno, M. Sasa, and S. Takaori (1987) Excitatory and inhibitory effects of dopamine on neuronal activity of the caudate nucleus in vitro. Brain Res. 418: 262-272.

Akaoka, H., F. Saunier, and G. Chouvet (1987) Neuronal responses to dopamine in rat striatum: Comparison between dopamine iontophoretic application and nigro-striatal pathway stimulation. Biog. Amines 4: 407-412.

Albala, B. J., S. L. Moshe, J. F. Cubells, N. S. Sharpless, and M. H. Makman (1986) Unilateral peri-substantia nigra catecholaminergic lesion and amygdala kindling. Brain Res. 370:388-392.

Amato, G., G. Crescimanno, F. Sorbera, and LaGrutta V. (1982) Relationship between the striatal system and amygdaloid paroxysmal activity. Exp. Neurol. 77: 492-504.

Anlezark, G. M., and B. S. Meldrum (1975) Effects of apomorphine, ergocornine and piribedil on audiogenic seizures in DBA $/ 2$ mice. $\mathrm{Br}$. J. Pharmacol. 53: 419-421.

Barsa, J. A., and N. S. Kline (1955) Treatment of two hundred disturbed psychotics with reserpine. JAMA 158: 110-113. 
Bennet, J. P. (1986) Striatal dopamine depletion, dopamine receptor stimulation, and GABA metabolism: Implications for the therapy of Parkinsons disease. Ann. Neurol. 19: 194-196.

Besson, M. J., M. L. Kemel, C. Gauchy, and J. Glowinsky (1982) Bilateral asymmetrical changes in the nigral release of $\left[{ }^{3} \mathrm{H}\right] \mathrm{GABA}$ induced by unilateral application of acetylcholine in the cat caudate nucleus. Brain Res. 241: 241-248.

Björklund, A., and O. Lindvall (1984) Dopamine-containing systems in the CNS. In Handbook of Chemical Neuroanatomy. Classical Transmitters in the CNS, Vol. 2/I, A. Björklund and T. Hökfelt, eds., pp. 55-122, Elsevier, Amsterdam.

Bowery, N. G., A. L. Hudson, and G. W. Price (1987) GABA $_{A}$ and $\mathrm{GABA}_{\mathrm{B}}$ receptor site distribution in the rat central nervous system. Neuroscience 20:365-383.

Brown, J. R., and G. W. Arbuthnott (1983) The electrophysiology of dopamine $\left(\mathrm{D}_{2}\right)$ receptors: A study of the actions of dopamine on corticostriatal transmission. Neuroscience 10: 349-355.

Burchfiel, J. L., C. D. Applegate, and R. J. Konkol (1986) Kindling antagonism: A role for norepinephrine in seizure suppression. In Kindling 3, J. A. Wada, ed., pp. 213-226, Raven, New York.

Callaghan, D. A., and W. S. Schwark (1979) Involvement of catecholamines in kindled amygdaloid convulsions in the rat. Neuropharmacology 18: 541-545.

Cavalheiro, E. A., and L. Turski (1986) Nigrostriatal dopamine regulates the seizure threshold of the limbic forebrain. Soc. Neurosci. Abstr. 12: 898

Cavalheiro, E. A., Z. A. Bortolotto, and L. Turski (1987) Microinjections of the $\gamma$-aminobutyrate antagonist, bicuculline methiodide, into the caudate-putamen prevent amygdala-kindled seizures in rats. Brain Res. 411: 370-372.

Chkhenkeli, S. A. (1978) Inhibitory influences of caudate stimulation on the epileptic activity of human amygdala and hippocampus during temporal lobe epilepsy. Izv. Akad. Nauk GSSR 4: 406-411.

Clifford, D. B., J. W. Olney, A. Maniotis, R. C. Collins, and C. F. Zorumski (1987) The functional anatomy and pathology of lithiumpilocarpine and high-dose pilocarpine seizures. Neuroscience 23:953968.

Corcoran, M. E. (1981) Catecholamines and kindling. In Kindling 2, J. A. Wada, ed., pp. 87-104, Raven, New York

DeLong, M. R., A. P. Georgopoulos, M. D. Croutcher, S. J. Mitchell, R. T. Richardson, and G. E. Alexander (1984) Functional organisation of the basal ganglia: Contribution of single-cell recording studies. In Functions of the Basal Ganglia, D. Evered and M. O'Connor, eds., pp. 64-78, Pitman, London.

Engel, J., and N. S. Sharpless (1977) Long-lasting depletion of dopamine in the rat amygdala induced by kindling stimulation. Brain Res. 136: 381-386.

Fink, R. P., and L. Heimer (1967) Two methods for selective impregnations of degenerating axons and their synaptic endings in the central nervous system. Brain Res. 4: 369-374.

Gale, K., and M. Casu (1981) Dynamic utilization of GABA in substantia nigra. Regulation by dopamine and GABA in the striatum, and its clinical and behavioral implications. Mol. Cell. Biochem. 39: 369-405.

Gee, K. W., M. A. Hollinger, J. F. Bowyer, and E. K. Kiliam (1979) Effect of seizures kindled by subconvulsant doses of pentylenetetrazol on dopamine receptor binding and dopamine-sensitive adenylate cyclase in the rat. Exp. Neurol. 66: 771-777.

Gerfen, C. R. (1984) The neostriatal mosaic: Compartmentalization of corticostriatal input and striatal output systems. Nature 311:461464.

Gerfen, C. R., K. G. Baimbridge, and J. Thibault (1987a) The neostriatal mosaic: III. Biochemical and developmental dissociation of patch-matrix mesostriatal systems. J. Neurosci. 7: 3935-3944.

Gerfen, C. R., M. Herkenham, and J. Thibault (1987b) The neostriatal mosaic: II. Patch- and matrix-directed mesostriatal dopaminergic and non-dopaminergic systems. J. Neurosci. 7: 3915-3934.

Graybiel, A. M., and C. W. Ragsdale (1983) Biochemical anatomy of the striatum. In Chemical Neuroanatomy, P. C. Emson, ed., pp. 427504, Raven, New York.

Graybiel, A. M., R. W. Baughman, and F. Eckenstein (1986) Cholinergic neuropil of the striatum observes striosomal boundaries. Nature 323: $625-628$.

Hayashi, T. (1953) The efferent pathway of epileptic seizures for the face following cortical stimulation differs from limbs. Jpn. J. Pharmacol. 4: 306-321.
Heimer, L., G. F. Alheid, and L. Zaborszky (1985) Basal ganglia. In The Rat Nervous System, G. Paxinos, ed., pp. 37-86, Academic, Sydney.

Herrling, P. L., and C. D. Hull (1980) Iontophoretically applied dopamine depolarizes and hyperpolarizes the membrane of cat caudate neurons. Brain Res. 192: 441-462.

Hiramatsu, M., N. Fujimoto, and A. Mori (1982) Catecholamine level in cerebrospinal fluid of epileptics. Neurochem. Res. 7: 1299-1305.

Hornykiewicz, O. (1966) Dopamine (3-hydroxytyramine) and brain function. Pharmacol. Rev. 18: 925-964.

Iadarola, M. J., and K. Gale (1982) Substantia nigra: Site of anticonvulsant activity mediated by $\gamma$-aminobutyric acid. Science $218: 1237$ 1240 .

Iorio, L. C., A. Barnett, F. H. Leitz, V. P. Houser, and C. A. Korduba (1983) SCH 23390, a potential benzazepine antipsychotic with unique interactions on dopaminergic systems. J. Pharmacol. Exp. Ther. 226: $462-468$.

Iversen, S. D. (1977) Brain dopamine systems and behavior. In Handbook of Psychopharmacology. Drugs, Neurotransmitters, and Behavior, L. L. Iversen, S. D. Iversen, and S. H. Snyder, eds., pp. 333-384, Plenum, New York.

Kesner, R. P. (1966) Subcortical mechanisms of audiogenic seizures. Exp. Neurol. 15: 192-205.

König, J. F. R., and R. A. Klippel (1963) The Rat Brain: A Stereotaxic Atlas of the Forebrain and Lower Parts of the Brain Stem, Williams \& Wilkins, Baltimore.

Kryzhanovskii, G. N., A. A. Shandra, R. F. Makulkin, L. S. Godlevskii, and I. N. Moiseev (1985) Effect of destruction of the hippocampus and caudate nucleus on development of epileptic activity associated with metrazol kindling. Bull. Exp. Biol. Med. 100: 407-410.

Kusske, J. A. (1979) Corticocaudatothalamic interactions in experimental focal epilepsy in the cat. Exp. Neurol. 65: 616-624.

Lewis, J., V. Westerberg, and M. E. Corcoran (1987) Monoaminergic correlates of kindling. Brain Res. 403: 205-212.

Loopuijt, L. D., J. B. Sebens, and J. Korf (1987) A mosaic-like distribution of dopamine receptors in rat neostriatum and its relationship to striosomes. Brain Res. 405: 405-408.

Löschcr, W., and S. J. Czuczwar (1986) Studies on the involvement of dopamine D-1 and D-2 receptors in the anticonvulsant effect of dopamine agonists in various rodent models of epilepsy. Eur. J. Pharmacol. 128: 55-65.

Löscher, W., and W. S. Schwark (1987) Further evidence for abnormal GABAergic circuits in amygdala-kindled rats. Brain Res. 420: 385390.

Marsden, C. D. (1984) Functions of the basal ganglia as revealed by cognitive and motor disorders in Parkinsons disease. Can. J. Neurol. Sci. 11: 129-135.

McGeer, E. G., W. A. Staines, and P. L. McGeer (1984) Neurotransmitters in the basal ganglia. Can. J. Neurol. Sci. 11: 89-99.

McIntyre, D. C. (1981) Catecholamine involvement in amygdala kindling of the rat. In Kindling 2, J. A. Wada, ed., pp. 67-85, Raven, New York.

McNamara, J. O., M. T. Galloway, L. C. Rigsbee, and C. Shin (1984) Evidence implicating substantia nigra in regulation of kindled seizure threshold. J. Neurosci. 4: 2410-2417.

McNamara, J. O., D. W. Bonhaus, B. G. Crain, R. L. Gellman, G. L. Giacchino, and C. Shin (1985) The kindling model of epilepsy: $\Lambda$ critical review. CRC Crit. Rev. Clin. Neurobiol. 1: 341-393.

Meldrum, B. S., G. M. Anlezark, and M. Trimble (1975) Drugs modifying dopaminergic activity and behaviour, the EEG and epilepsy in Papio papio. Eur. J. Pharmacol. 32: 203-213.

Meldrum, B. S., L. Turski, M. Schwarz, S. J. Czuczwar, and K.-H. Sontag (1986) Anticonvulsant action of 1,3-dimethyl-5-aminoadamantane. Pharmacological studies in rodents and baboon, Papio papio. Naunyn Schmiedebergs Arch. Pharmacol. 332: 93-97.

Mercuri, N., G. Bernardi, P. Calabresi, A. Cotugno, G. Levi, and P. Stanzione (1985) Dopamine decreases cell excitability in rat striatal neurons by pre- and postsynaptic mechanisms. Brain Res. 358:110121.

Mori, A., M. Hiramatsu, S. Namba, A. Nishimoto, T. Ohmoto, Y. Mayanagi, and T. Asakura (1987) Decreased dopamine level in the epileptic focus. Res. Commun. Chem. Pathol. Pharmacol. 56: 157164.

Mutani, R. (1969) Experimental evidence for the existence of an extrarhinencephalic control of the activity of the cobalt rhinencephalic 
epileptogenic focus. Part 1 . The role played by the caudate nucleus. Epilepsia 10: 337-350.

Nagy, J. I., S. R. Vincent, and II. C. Fibiger (1978) Altered neurotransmitter synthetic enzyme activity in some extrapyramidal nuclei after lesions of the nigro-striatal dopamine projection. Life Sci. 22: 1777-1782.

Oades, R. D., and G. M. Halliday (1987) Ventral tegmental (A 10) system: Neurobiology. 1. Anatomy and connectivity. Brain Res. Rev. 12: $117-165$.

Oakley, J. C., and G. A. Ojemann (1982) Effects of chronic stimulation of the caudate nucleus on a preexisting alumina seizure focus. Exp. Neurol. 75: 360-367.

Ohno, Y., M. Sasa, and S. Takaori (1985) Dopamine $D_{2}$ receptormediated excitation of caudate nucleus neurones from the substantia nigra. Life Sci. 37: 1515-1521.

Ohno, Y., M. Sasa, and S. Takaori (1986) Excitation by dopamine D, receptor agonist, bromocriptine and LY 171555 , in caudatc nucleus neurons activated by nigral stimulation. Life Sci. 38: 1867-1873.

Olney, J. W., T. de Gubareff, and J. Labruyere (1983) Seizure-related brain damage induced by cholinergic agents. Nature 301: 520-522.

Ono, K., K. Mori, H. Baba, and J. A. Wada (1987) A role of the striatum in premotor cortical seizure development. Brain Res. 435 : 84-90.

Patel, S., M. H. Millan, L. M. Mello, and B. S. Meldrum (1986) 2Amino-7-phosphonoheptanoic acid (2-APH) infusion into entopeduncular nucleus protect against limbic seizures in rats. Neurosci. Lett. 64: 226-230.

Psatta, D. M. (1983) Control of chronic experimental focal epilepsy by feedback caudatum stimulations. Epilepsia 24: 444-454.

Quesney, L. F., F. Andermann, S. Lai, and S. Prelevic (1980) Transient abortion of generalized photosensitive epileptic discharge in humans by apomorphine, a dopamine-receptor agonist. Neurology 30:11691174.

Racine, R. J. (1972) Modification of seizure activity by electrical stimulation. II. Motor seizure. Electroencephalogr. Clin. Neurophysiol. 32: 281-294.

Richfield, E. K., A. B. Young, and J. B. Penney (1987) Comparative distribution of dopamine D-1 and D-2 receptors in the basal ganglia of turtles, pigeons, rats, cats, and monkeys. J. Comp. Neurol. 262: $446-463$.

Sabatino, M., G. Morici, V. Savatteri, M. Scaturro, and V. La Grutta (1987) Nigral control of hippocampal epileptiform activity. Clin. Neurol. Neurosurg. 89-2: 108.

Seeman, P., and D. Grigoriadis (1987) Dopamine receptors in brain and periphery. Neurochem. Int. 10: 1-34.

Setler, P. E., H. M. Saran, C. L. Zirkle, and H. L. Saunders (1978) The central effects of a novel dopamine agonist. Eur. J. Pharmacol. 50: 419-430.

Sherwin, A. L., and N. M. van Gelder (1986) Amino acid and catecholamine markers of metabolic abnormalities in human focal epilepsy. Adv. Neurol. 44: 1011-1032.

Shin, C., and J. O. McNamara (1986) Stimulation of substantia nigra pars reticulata increases the excitability of dentate granule cells of rat hippocampus. Soc. Neurosci. Abstr. 12: 652 .

Sramka, M., G. Fritz, D. Gajdosova, and P. Nadvornik (1980) Central stimulation treatment of epilepsy. Acta Neurochir. Suppl. 30: 183187.
Trugman, J. M., W. A. Geary, and G. F. Wooten (1986) Localization of D-2 dopamine receptors to intrinsic striatal neurones by quantitative autoradiography. Nature 323: 267-269.

Tsuruta, K., E. A. Frey, C. W. Grewe, T. E. Cote, R. L. Eskay, and J. W. Kebabian (1981) Evidence that LY-141865 specifically stimulates the $\mathrm{D}_{2}$ dopamine receptor. Nature 292: 463-465.

Turski, L., E. A. Cavalheiro, W. A. Turski, and B. S. Meldrum (1986a) Excitatory neurotransmission within substantia nigra pars reticulata regulates threshold for seizures produced by pilocarpine in rats: Effects of intranigral 2-amino-7-phosphonoheptanoate and N-methyl-D-aspartate. Neuroscience $18: 61-77$.

Turski, L., S. Diedrichs, C. Heim, Z. A. Bortolotto, E. A. Cavalheiro, M. Schwarz, T. Klockgether, and K.-H. Sontag (1986b) Striatal CrABA regulates the threshold for seizures in the limbic system: Bicuculline is anticonvulsant in the rat caudate-putamen. Naunyn Schmiedebergs Arch. Pharmacol. 334: R51.

Turski, L., E. A. Cavalheiro, S. J. Czuczwar, W. A. Turski, and Z. Kleinrok (1987a) The seizures induced by pilocarpine: Behavioral electroencephalographic and neuropathological studies in rodents. Pol. J. Pharmacol. Pharm. 39: 413-423.

Turski, L., E. A. Cavalheiro, W. A. Turski, and B. S. Meldrum (1987b) Role of a striatonigral pathway in regulation of the threshold for limbic seizures in rats. In Advances in Epileptology, Vol. 16, P. Wolf, M. Dam, D. Janz, and F. F. Dreifuss, eds., pp. 115-118, Raven, New York.

Turski, L., B. S. Meldrum, E. A. Cavalheiro, L. S. Calderazzo-Filho, Z. A. Bortolotto, C. Ikonomidou-Turski, and W. A. Turski $(1987 \mathrm{c})$ Paradoxical anticonvulsant activity of the excitatory amino acid $\mathrm{N}$. methyl-D-aspartate in the rat caudate-putamen. Proc. Natl. Acad. Sci. USA 84: 1689-1693.

Turski, W. A., S. J. Czuczwar, Z. Kleinrok, and L. Turski (1983) Cholinomimetics produce seizures and brain damage in rats. Experientia 39: 1408-1411.

Turski, W. A., E. A. Cavalheiro, Z. A. Bortolotto, L. E. A. Moraes Mello, M. Schwarz, and L. Turski (1984) Seizures produced by pilocarpine in mice: A behavioral, electroencephalographic and morphological analysis. Brain Res. 321: 237-253.

Wada, J. A., and A. Wake (1977) Dorsal frontal, orbital and mesial frontal cortical lesions and amygdaloid kindling in cats. Can. J. Neurol. Sci. 4: 107-115.

Wagner, H. R., D. M. Feency, F. P. Gullotta, and I. L. Cote (1975) Suppression of cortical epileptiform activity by generalized and localized ECoG desynchronization. Electroencephalogr. Clin. Neurophysiol. 39: 499-506.

Wamsley, J. K., M. A. Zarbin, and M. J. Kuhar (1984) Distribution of muscarinic cholinergic high and low affinity agonist binding sites: A light microscopic autoradiographic study. Brain Res. Bull. 12:233243.

White, J. D., and C. M. Gall (1987) Differential regulation of neuropeptide and proto-oncogene mRNA content in the hippocampus following recurrent seizures. Mol. Brain Res. 3: 21-29.

Wilkison, D. M., and L. M. Halpern (1979) Turnover kinetics of dopamine and norepinephrine in the forebrain after kindling in rats. Neuropharmacology 18: 219-222. 